\title{
Hemafereza lecznicza w świetle danych przedstawionych w czasie 36. Międzynarodowego Kongresu ISBT (kongres wirtualny, 12-16 grudnia 2020 r.). Cześć II - cytafereza lecznicza
}

\author{
Therapeutic hemapheresis in light of the presentations at the 36th \\ International ISBT Congress Virtual meeting, 12-16 December 2020. \\ Part II - therapeutic cytapheresis
}

\author{
Aleksandra Rosiek $\odot$ \\ Zakład Transfuzjologii Instytutu Hematologii i Transfuzjologii w Warszawie
}

\begin{abstract}
Streszczenie
Wramach 36. Międzynarodowego Kongresu ISBT (kongres wirtualny, 12-16 grudnia 2020 r.) hemaferezie leczniczej poświęcono tacznie 22 doniesienia omawiajace różne aspekty stosowania tej metody leczniczej. Przedstawiono dane dotyczace wykorzystania wybranych technik hemaferezy w niektórych chorobach $i$ stanach klinicznych.

Najwięcej doniesień (8) pochodzito z Hiszpanii ( $w$ tym jedno we wspótpracy $z$ USA), po 2 z Korei $i$ ze Sri Lanki. Przedstawiono również pojedyncze doniesienia z Polski, Wielkiej Brytanii, Indii, Meksyku, Omanu, Bangladeszu, Argentyny i Izraela.

Większość doniesień (14) poświęcono zagadnieniom zwiazanym ze stosowaniem plazmaferezy leczniczej - między innymi w neurologii i w przypadkach zakrzepowej plamicy matoptytkowej. Niniejsza (druga) część sprawozdania jest poświecona prezentacjom dotyczacym cytaferezy leczniczej, natomiast doniesienia na temat plazmaferezy leczniczej zostaty przedstawione w czéści pierwszej.
\end{abstract}

Słowa kluczowe: hemafereza lecznicza, cytafereza, leukafereza, trombafereza, fotofereza

J. Transf. Med. 2021; 14: 87-92

\section{Wstęp}

W ramach 36. Międzynarodowego Kongresu ISBT (kongres wirtualny, 12-16 grudnia 2020 r.), hemaferezie leczniczej poświęcono część sesji plakatowej obejmującej zagadnienia $\mathrm{z}$ zakresu transfuzjologii klinicznej, a także część sesji dotyczącej prezentacji wyników badań klinicznych. Ponadto doniesienia na temat fotoferezy były przedstawiane w sesjach poświęconych zastosowaniom terapii komórkowych.

Prezentacje poszczególnych prac zostały umieszczone na stronie internetowej kongresu $\mathrm{w}$ postaci filmów zawierających slajdy $\mathrm{z}$ nagranym komentarzem autorskim.

Adres do korespondencji: dr n. med. Aleksandra Rosiek, Zakład Transfuzjologii Instytutu Hematologii i Transfuzjologii, ul. I. Gandhi 14, 02-776 Warszawa, tel.: 2234963 91, faks: 2234963 76, e-mail: arosiek@ihit.waw.pl

Opracowano na podstawie: Vox Sanguinis 2020; 115 (supl. 1): 3-387

Artykuł jest dostępny bezpłatnie na podstawie licencji Creative Common Attribution-Non-Commercial-No Derivatives 4.0 International (CC BY-NC-ND 4.0) umożliwiającej jego pobranie oraz udostępnianie pod warunkiem wskazania autorstwa i wydawcy. Niedopuszczalne jest wprowadzanie jakichkolwiek zmian lub wykorzystanie komercyjne bezzgody wydawcy. 
Przedstawiono łącznie 22 doniesienia omawiające różne aspekty stosowania hemaferezy leczniczej w niektórych chorobach i stanach klinicznych, przy czym:

- w 14 doniesieniach poruszano zagadnienia związane ze stosowaniem plazmaferezy;

- 1 doniesienie dotyczyło erytroaferezy;

- 1 doniesienie poświęcono zastosowaniu leukaferezy;

- 1 doniesienie dotyczyło wieloletnich doświadczeń autorów związanych ze stosowaniem różnych technik aferezy leczniczej;

- 5 doniesień obejmowało temat fotoferezy. Najwięcej doniesień (8) pochodziło $z$ Hiszpanii (w tym jedno we współpracy z Stanami Zjednoczonymi), po 2 z Korei i ze Sri Lanki. Przedstawiono również pojedyncze doniesienia $z$ Polski, Wielkiej Brytanii, Indii, Meksyku, Omanu, Bangladeszu, Argentyny i Izraela.

Niniejsza część sprawozdania poświęcona jest zastosowaniom cytaferezy leczniczej, natomiast doniesienia na temat plazmaferezy leczniczej zostały przedstawione w części pierwszej niniejszego sprawozdania [1].

\section{Doświadczenia związane ze stosowaniem cytaferezy leczniczej w różnych stanach klinicznych}

W doniesieniu pochodzącym $z$ Polski (Rosiek i wsp.) przedstawiono dane dotyczące zabiegów hemaferezy wykonanych w latach 1997-2017 w Instytucie Hematologii i Transfuzjologii (IHiT) w Warszawie [2]. Analizowano wskazania do zabiegów, ich liczbę w poszczególnych latach, a także kategorię przypisywaną danemu zastosowaniu hemaferezy według zaleceń Amerykańskiego Stowarzyszenia Aferezy (ASFA, American Society for Apheresis) [3].

W omawianym okresie wykonano łącznie 3635 zabiegów u 778 pacjentów, w tym 717 zabiegów leukaferezy u 286 pacjentów, 97 zabiegów trombaferezy u 38 pacjentów i 79 zabiegów fotoferezy u 7 pacjentów (dane dotyczące zabiegów plazmaferezy zostały przedstawione w części pierwszej niniejszego sprawozdania) [1].

Zabiegi w IHiT wykonano głównie u pacjentów $z$ chorobami układu krwiotwórczego. Zabiegi leukaferezy przeprowadzano w celu wyeliminowania nadmiaru leukocytów w przebiegu białaczki, zarówno w stanach leukostazy, jak i profilaktycznie, natomiast zabiegi trombaferezy - w celu eliminacji nadmiaru płytek krwi u chorych $z$ trombocytozą.
Poczynając od grudnia 2016 roku, wykonywano zabiegi fotoferezy u pacjentów $z$ chorobą przeszczep przeciwko gospodarzowi (GvHD, graft-versus-host disease) po przeszczepieniu krwiotwórczych komórek macierzystych.

Większość $z$ tych zabiegów spełniało kryteria wskazań do stosowania hemaferezy wedłg wytycznych ASFA, chociaż nie zawsze były to zalecenia I kategorii ${ }^{1}$.

Zabiegi były na ogół dobrze tolerowane, a obserwowane niepożądane reakcje dotyczyły łagodnych reakcji wazowagalnych i objawów hipokalcemii, a także problemów $z$ dostępem naczyniowym.

Autorzy stwierdzają, że hemafereza lecznicza, w tym cytafereza, jest przede wszystkim zabiegiem o działaniu wspomagającym i paliatywnym, służącym najczęściej do szybkiej eliminacji czynników chorobotwórczych $z$ krążenia. Warto jednak zauważyć, że zabiegi te są zawsze kosztowne i związane $z$ pewnym ryzykiem dla pacjenta, należy je zatem stosować $z$ należytą rozwagą, po przeprowadzeniu odpowiedniej oceny klinicznej.

\section{Erytroafereza lecznicza}

Erytroafereza jest techniką aferezy polegającą na automatycznej separacji krwinek czerwonych chorego i zastąpieniu ich koncentratem krwinek czerwonych $(\mathrm{KKCz})$ dawcy lub płynem zastępczym. Erytroaferezie poświęcono w czasie sesji plakatowej jedno doniesienie, omawiające jej zastosowanie w leczeniu niedokrwistości sierpowatokrwinkowej.

W badaniu Martinez Lázaro i wsp. (Hospital Clínico Universitario Lozano Blesa, Saragossa, Hiszpania) omówiono zagadnienia związane $z$ leczeniem 4-letniego chłopca $z$ niedokrwistością sierpowatokrwinkową [4]. W sierpniu 2018 roku chłopiec przebył udar niedokrwienny lewej tętnicy środkowej mózgu. W okresie od września 2018 roku do stycznia 2020 roku u dziecka wykonano łącznie 7 zabiegów erytroaferezy. Obserwowano problemy dotyczące dostępu żylnego, co wiązało się z koniecznością przerywania serii zabiegów i stosowania portu naczyniowego. $\mathrm{W}$ okresach, gdy nie wykonywano erytroaferezy, chłopiec otrzymywał przetoczenia $\mathrm{KKC} z$, co jednak doprowadziło u niego do przeciążenia żelazem i w konsekwencji do konieczności zastosowania leków chelatujących żelazo.

\footnotetext{
${ }^{1}$ Według wskazań ASFA z 2019 r. wyróżniano cztery kategorie zaleceń do zabiegu aferezy leczniczej:

- Kategoria I - afereza jako terapia pierwszego rzutu, stosowana samo-

- Kategoria - afereza jako terapia pierwszego rzutu, stos

- Kategoria II - afereza jako terapia drugiego rzutu, stosowana samodzielnie lub w połączeniu z innymi metodami leczenia.

- Kategoria III - optymalne zastosowania aferezy nieustalone, decyzje należy podejmować indywidualnie.

- Kategoria IV - opublikowano dowody na brak skuteczności lub szkodliwość aferezy.
} 
W okresie, gdy stosowano aferezę, poziom hemoglobiny $\mathrm{S}$ u pacjenta utrzymywał się przed zabiegami na poziomie $35,1 \%$, a po erytroferezie $-10,4 \%$, przy wartości Hct $<35 \%$. W chwili zgłaszania doniesienia stan pacjenta był stabilny, a przeciążenie żelazem ulegało zmniejszeniu; nie stwierdzono alloimmunizacji.

Autorzy stwierdzają, że erytrofereza wykonywana u dzieci $z$ niedokrwistością sierpowatokrwinkową jest zabiegiem bezpiecznym i skutecznym. Stosując ją jednak w praktyce klinicznej, należy dysponować odpowiednimi procedurami, związanymi z koniecznością zapewnienia dostępu do żył obwodowych.

\section{Leukafereza lecznicza}

Jako najczęstsze wskazanie do zabiegu leukaferezy leczniczej, tj. zabiegu mającego na celu separację metodą aferezy leukocytów pacjenta, wymieniana jest $\mathrm{w}$ piśmiennictwie światowym redukcja nadmiaru leukocytów u chorych $z$ białaczką.

Założeniem badania opisanego przez Lee i wsp. (Seoul St. Mary's Hospital, Seul, Republika Korei) była ocena skutków stosowania leukaferezy u pacjentów $z$ różnymi rodzajami białaczek [5].

W tym celu wybrano do badania 319 pacjentów $z$ nowo rozpoznaną ostrą białaczką ( $z$ wyłączeniem ostrej białaczki promielocytowej), przechodzących zabiegi leukaferezy w latach 2009-2018, i dokonano ich kwalifikacji zgodnie z klasyfikacją Światowej Organizacji Zdrowia (WHO, World Health Organization) z 2016 roku. Byli to pacjenci z pierwotną ostrą białaczką szpikową - 200 osób; z wtórną białaczką szpikową -12 osób; z ostrą białaczką limfoblastyczną - 97 osób, oraz 10 pacjentów $z$ ostrą białaczką o mieszanym fenotypie. Średnia początkowa liczba leukocytów u pacjentów wynosiła od 152,5 do $263,7 \times 10^{9} / 1$.

Skuteczność leukaferezy oceniano na podstawie uzyskanego zmniejszenia bezwzględnej liczby leukocytów. Wyróżniono dwie grupy pacjentów o większym stopniu cytoredukcji (53 osoby; średni czas przeżycia 1187 dni) i o mniejszym stopniu (266 osób; średni czas przeżycia $1753 \mathrm{dni}$ ), $\mathrm{p}=0,042$. $\mathrm{W}$ grupie pacjentów $z$ ostrą białaczką szpikową średnie wartości czasu przeżycia w wymienionych grupach wynosiły odpowiednio 1023 i 1759 dni, a u pacjentów $z$ ostrą białaczką limfoblastyczną 946 i 1781 dni.

Autorzy wnioskują, że całkowity czas przeżycia pacjentów $z$ ostrą białaczką był odwrotnie proporcjonalny do uzyskanej redukcji liczby leukocytów, co prawdopodobnie odzwierciedla podstawową patobiologię białaczki. Jednak wskazane wydaje się przeprowadzenie dalszych badań.

\section{Fotofereza}

Fotofereza (ECP, extracorporeal photopheresis,) jest ważną metodą terapii komórkowej. Międzynarodowy standard wykonania fotoferezy przewiduje pobranie limfocytów pacjenta metodą leukaferezy, dodanie do nich ex vivo fotouczulacza (8-metoksypsoralen), a następnie naświetleniu ich ultrafioletem A i przetoczenie zwrotnie pacjentowi. Mechanizm działania ECP nie jest jeszcze w pełni poznany. Przypuszcza się jednak, że podstawową rolę odgrywa w nim indukcja apoptozy komórek.

Podstawowe metody wykonywania fotoferezy to:

- metoda online albo jednostopniowa (w zintegrowanym, zamkniętym systemie),

- metoda offline albo dwustopniowa [(przy użyciu separatora komórkowego i oddzielnego urządzenia do naświetlania promieniowaniem ultrafioletowym A (UVA, ultraviolet $A$ rays)].

Większość prezentowanych w czasie kongresu doniesień dotyczących różnych aspektów stosowania fotoferezy pochodziła $z$ Hiszpanii (4 doniesienia), jedno natomiast $z$ Izraela.

Pierwsza $z$ prac poświęconych fotoferezie (Navarro i wsp.) pochodziła $z$ Hiszpanii (Hospital La Fe, Walencja) [6]. Autorzy oceniali wykonalność i skuteczność stosowania fotoferezy u pacjentów pediatrycznych, u których po przeszczepieniu komórek krwiotwórczych wystąpiła choroba przeszczep przeciwko biorcy (TA-GvHD, transfusion-associated graft-versus-host disease). Wykonywanie zabiegów u dzieci wiąże się ze szczególnymi problemami ze względu na mniejszą całkowitą objętość krwi chorego, utrudniony dostęp żylny, brak współpracy i nieraz większe ryzyko powikłań.

Badaniem objęto pacjentów w wieku poniżej 18 lat. W latach 2013-2015 stosowano jednostopniową metodę fotoferezy, wykonując dwie sesje ECP w tygodniu (ostra GvHD) lub co dwa tygodnie (przewlekła GvHD). Poczynając od 2016 roku, stosowano metodę dwustopniową, wykonując dwie sesje ECP w tygodniu (ostra GvHD) lub raz w tygodniu (przewlekła GvHD), a następnie jedną sesję co dwa tygodnie. Pacjenci $z$ masą ciała $<25 \mathrm{~kg}$ otrzymywali dożylnie wapń, a system aferezy wypełniano przed zabiegiem krwią. W 85\% przypadków zastosowano centralny cewnik żylny.

Wykonano łącznie 516 sesji ECP podczas 27 epizodów leczenia u 23 pacjentów (2 pacjentów 
miało 3 epizody), w wieku od 1 do 16 lat (mediana 8 lat), o masie ciała od 8 do $86 \mathrm{~kg}$ (mediana $29 \mathrm{~kg}$ ). Mediana liczby sesji na pacjenta wynosiła 16 (zakres 2-47), a mediana czasu stosowania zabiegów -5 miesięcy (zakres 0,25-15). Połowę zabiegów wykonano u pacjentów o masie ciała $<25 \mathrm{~kg}$ $(\mathrm{n}=262)$. Wskazaniem do leczenia była przewlekła GvHD w 10 przypadkach (37\%), a w pozostałych ostra GvHD [obejmująca skórę (23/27; $85 \%)$, jelita $(10 / 27 ; 37 \%)$ i wątrobę $(6 / 27 ; 22 \%)]$.

Wydajność zbierania limfocytów była wyższa w trybie offline (49\% vs. $40 \%$ ). Większość problemów obserwowanych podczas zabiegów była związana $z$ dysfunkcją centralnego cewnika żylnego (70/516; 13\%), ale tylko 3 sesje musiały zostać przerwane. Pozostałe incydenty to lekka hipokalcemia $(\mathrm{n}=8 ; 1,5 \%)$, niedokrwistość związana $z \operatorname{ECP}(\mathrm{n}=7 ; 1,3 \%)$, problemy techniczne $(\mathrm{n}=6$; $1 \%)$ i niedociśnienie $(\mathrm{n}=1)$.

Dwóch pacjentów zmarło przed zakończeniem pierwszego miesiąca leczenia. Pozostali wykazali pod koniec leczenia odpowiedź całkowita (32\%), częściową (32\%) lub brak odpowiedzi (36\%).

Autorzy wnioskują, że stosowanie zabiegów ECP jest wykonalne i bezpieczne, nawet w przypadku małych dzieci. Pomimo ograniczeń związanych $z$ opisywanym badaniem odpowiedź zaobserwowano u $64 \%$ pacjentów; ECP należy zatem rozważyć jako opcję leczenia GvHD u każdego dziecka.

Autorzy następnego doniesienia pochodzącego z Hiszpanii (Paciello Coronel i wsp.; Hospital 12 de Octubrere, Madryt) opisują wyniki zastosowania badania kinetyki apoptozy indukowanej procedurą ECP jako testu umożliwiającego biologiczną walidację ECP [7]. W tym celu oceniano ilościowo wczesną i późną apoptozę występującą po zabiegach $\mathrm{w}$ porównaniu $\mathrm{z}$ apoptozą komórek nie poddawanych ECP. Fotoferezę wykonywano metodą offline, przy użyciu separatora komórkowego i oddzielnego urządzenia do naświetlania UVA. Badanie obejmowało 8 zabiegów ECP u 5 pacjentów.

Badania kinetyki apoptozy wykazały istnienie znaczącej różnicy odsetka komórek apoptotycznych w próbkach pobranych przed i po ECP, a także 48 godzin po zabiegu. Autorzy wnioskują, że ocena apoptozy jest przydatną metodą walidacji procedur ECP, jakkolwiek ze względu na mała liczbę przeanalizowanych zabiegów opinia ta wymaga jeszcze potwierdzenia.

Trzecia praca pochodząca $z$ Hiszpanii (Fernández Rodriguez i wsp.; Hospital Universitario Central de Asturias, Oviedo) omawiała zastosowanie fotoferezy w leczeniu zespołu Sézary'ego (SS,
Sézary syndrome) i erytrodermicznej postaci ziarniniaka grzybiastego (e-MF, erythrodermic mycosis fungoides) [8]. Niektóre $z$ aktualnych wytycznych zalecają stosowanie ECP w leczeniu erytrodermicznej postaci pierwotnie skórnych chłoniaków T-komórkowych (E-CTCL, erythrodermic primary cutaneous T-cell lymphoma). Jednak poziom dostępnych dowodów jest niski, brakuje kontrolowanych badań klinicznych $z$ randomizacją, a wyniki analiz przedstawiane przez poszczególnych autorów są bardzo zróżnicowane.

Autorzy opisali swoje doświadczenia związane ze stosowaniem ECP u pacjentów z SS i e-MF, poczynając od 2015 roku. W tym okresie zabiegi wykonano u 8 pacjentów w wieku od 48 do 76 lat. U 6 pacjentów (75\%) stwierdzono SS w zaawansowanym stadium, a u 2 - e-MF. Dla większości pacjentów $(62,5 \%)$ ECP stanowiło terapię pierwszego rzutu; 5 pacjentów otrzymało leczenie dodatkowe (kortykosteroidy, interferon, gemcytabina, metotreksat i chemioterapia). Tylko u 2 pacjentów stwierdzono adenopatię lub splenomegalię, u 7 chorych głównym objawem była erytrodemia.

Średnia liczba zabiegów ECP przypadająca na jednego pacjenta wyniosła 13,87 (4-24). Częściowe złagodzenie objawów skórnych zaobserwowano u 3 pacjentów (37,5\%), przy średniej liczbie zabiegów wykonanych w tej grupie 21,33 . U chorych nie wykazujących reakcji zabiegi zakończono wcześniej. Nie obserwowano powikłań związanych $z$ ECP, jakkolwiek u jednego $z$ pacjentów wykryto zakażenie centralnego cewnika żylnego.

Autorzy oceniają bezpieczeństwo i tolerancję ECP jako bardzo dobre. Uzyskany odsetek odpowiedzi był podobny do opisywanego poprzednio $\mathrm{u}$ chorych $z$ erytrodemią, jednak nie uzyskano pełnej odpowiedzi. Znaczny procent pacjentów wykazywał ogólnoustrojową progresję pomimo poprawy objawów skórnych, być może dlatego, że ECP wykonywano w zaawansowanych stadiach choroby. Autorzy stwierdzają, że seria ocenianych zabiegów była krótka, jednak potwierdza wskazanie, aby zastosowanie ECP u pacjentów z SS/e-MF, u których występują objawy skórne, rozważyć na jak najwcześniejszym etapie leczenia.

W ostatniej pracy pochodzącej z Hiszpanii (Medina Guerrero i wsp.; Hospital Universitari Son Espases, Palma de Mallorca) omówiono wyniki stosowania ECP w leczeniu przewlekłej GvHD (cGvHD, chronic graft-versus-host disease) po przeszczepieniu komórek krwiotwórczych [9]. Jest to opisowe badanie retrospektywne prze- 
prowadzone w szpitalu Universitari Son Espases w okresie od lutego 2015 do stycznia 2020 . W ramach tego badania analizowano dane kliniczne i biologiczne 11 pacjentów $z$ różnymi chorobami hematologicznymi w wieku od 20 do 69 lat. Do oceny nasilenia cGvHD wykorzystano skalę ocen National Institutes of Health (NIH) (łagodne, umiarkowane i ciężkie). Fotoferezę wykonywano metodą offline.

Mediana wieku pacjentów wynosiła 54 lata (zakres 20-69). U 2 pacjentów stwierdzono objawy lagodne, u 7 umiarkowane, a u 2 - ciężkie. U wszystkich pacjentów występowało zajęcie skóry i błon śluzowych (u 4 również oczu).

U 6 pacjentów (55\%) ECP zastosowano jako terapię drugiego rzutu, u $4(36 \%)$ - trzeciego, a u 1 (9\%) - szóstego. U 9 pacjentów (82\%) obserwowano odpowiedź kliniczną, podczas gdy u $2(18 \%)$ nie stwierdzono żadnego efektu.

W opinii autorów stosowanie ECP jako dodatku do terapii konwencjonalnej zapewniło znaczące efekty terapeutyczne, a w przypadku większości pacjentów było bezpieczne i dobrze tolerowane. Po zabiegu nie stwierdzono większych zmian stężenia hemoglobiny i liczby płytek krwi. W podsumowaniu stwierdzono, że w celu kontynuacji badań wskazane jest określenie zasad przeprowadzania standaryzowanej oceny odpowiedzi klinicznej oraz wykonanie prospektywnych kontrolowanych badań klinicznych.

Praca pochodząca $z$ Izraela (Dann i wsp., Blood Bank and Apheresis Unit, Rambam Health Care Campus, Kfar Yehoshua) zawierała ocenę efektywności pobierania komórek $z$ krwi obwodowej w celu wykonania ECP w trybie offline przy zastosowaniu separacji metodą ciągłą lub przerywaną [10]. W pobranych preparatach oceniano liczbę neutrofili, limfocytów i monocytów, a także hematokryt i liczbę płytek krwi.

Jak stwierdzono, mediana liczby płytek krwi $\mathrm{w}$ koncentracie uzyskanym metodą przerywaną była o $25 \%$ wyższa niż w przypadku metody ciągłej

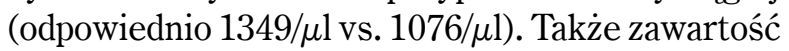
limfocytów i monocytów była większa w przypad$\mathrm{ku}$ metody przerywanej (odpowiednio $59 \%$ vs. $49 \%$ i $36 \%$ vs. $32 \%$ ). Mediana całkowitej liczby komórek jednojądrzastych $\mathrm{w}$ preparacie wynosiła odpowiednio $6 \times 10^{9} \mathrm{~W}$ przypadku metody przerywanej i $5 \times 10^{9}$ przy zastosowaniu metody ciaggłej. Natomiast mediana odsetka neutrofili była niższa w przypadkach metody przerywanej (odpowiednio $5,1 \%$ vs. $18,2 \%$ ).

$\mathrm{W}$ podsumowaniu autorzy stwierdzają, że obydwie stosowane metody zapewniały podobną jakość pobranego preparatu, jeżeli chodzi o liczbę WBC i wartość hematokrytu. Wprawdzie wyższy odsetek komórek jednojądrzastych i niższy neutrofili uzyskano, stosując procedurę przerywaną, jednak osiągnięto to kosztem o 25\% większej liczby płytek krwi w preparacie.

\section{Podsumowanie}

Hemafereza lecznicza, w tym różne techniki cytaferezy, to interesujące i podlegające ciągłym modyfikacjom metody lecznicze stosowane obecnie w terapii wielu chorób. Przydatność hemaferezy leczniczej w wielu stanach klinicznych nie została jednak dostatecznie udokumentowana, a kontrolowane badania są wciąż nieliczne.

Najwięcej prezentowanych w ramach omawianego kongresu doniesień pochodziło z Hiszpanii, co jednak przypuszczalnie można, przynajmniej częściowo, wiązać $z$ faktem, że tam właśnie w Barcelonie - miały się pierwotnie odbywać obrady. Zmiana charakteru kongresu na wirtualny nastąpiła już po zgłoszeniu prac, w związku $z$ wybuchem pandemii COVID-19.

Uwagę zwraca spora liczba prac poświęconych cieszącej się ostatnio znacznym zainteresowaniem metodzie fotoferezy (5 doniesień, czyli drugie miejsce po 14 doniesieniach omawiających zastosowania plazmaferezy leczniczej). Całkowicie zabrakło natomiast analiz poświęconych zastosowaniom leczniczej trombaferezy (poza podsumowaniem 20-letnich doświadczeń w pracy pochodzącej z Polski) [2].

Należy przy tym zwrócić uwagę na to, że doniesienia prezentowane $\mathrm{w}$ czasie naukowych kongresów nie zawsze odzwierciedlają aktualne trendy i skalę zastosowania hemaferezy leczniczej. W niektórych stanach klinicznych hemafereza lecznicza może obecnie tracić na znaczeniu w związku $z$ wprowadzaniem alternatywnych metod leczenia, co znajduje odzwierciedlenie między innymi w najszerzej obecnie stosowanych i cytowanych przez wielu autorów wytycznych ASFA (aktualizowanych ostatnio w czerwcu 2019 roku) [3]. Zgodnie jednak $z$ obserwacjami autorów omówionych powyżej prac przynajmniej w niektórych przypadkach hemafereza lecznicza, w tym cytafereza, nadal pozostaje przydatna jako uzupełniająca i pomocnicza metoda leczenia.

\section{Piśmiennictwo}

1. Rosiek A. Hemafereza lecznicza w świetle danych przedstawionych w czasie 36. Międzynarodowego Kongresu ISBT (kongres wirtualny, 12-16 grudnia 2020 r.). Cześć I — plazmafere- 
za lecznicza. J Transf Med. 2021; 14(1): 32-40, doi: 10.5603/ jtm.2021.0003.

2. Rosiek A, Lachert E, Antoniewicz-Papis J, et al. Two decades of therapeutic apheresis at the Warsaw Institute of Hematology and Transfusion Medicine. Vox Sanguinis. 2020; 115(suppl. s1): 310 .

3. Padmanabhan A, Connelly-Smith L, Aqui N, et al. Guidelines on the use of therapeutic apheresis in clinical practice - evidence-based approach from the Writing Committee of The American Society for Apheresis: the eighth special issue. J Clin Apher. 2019; 34(3): 171-354, doi: 10.1002/jca.21705, indexed in Pubmed: 31180581

4. Martines Lázaro B, Collado P, Auria C, et al. Erytroapheresis as secondary acute cerebrovascular accident prophylaxis in a patient with sickle cell disease. Vox Sanguinis. 2020; 115(Suppl. s1): 310 .

5. Lee H, Yoo J, Kim M, et al. Cytoreduction by leukapheresis was associated with unfavorable prognosis. Vox Sanguinis. 2020; 115(Suppl. s1): 311.
6. Navarro L, Moreno D, Bartual M, et al. Extracorporeal photopheresis $(\mathrm{ECP})$ in pediatric patients: a single-centre experience. Vox Sanguinis. 2020; 115(Suppl. s1): 57.

7. Paciello Coronel M, Leivas Aldea A, Redondo Velao S, et al. One Center experience in offline technique validation with biological quality tests. Vox Sanguinis. 2020; 115(Suppl. s1): 366.

8. Fernandez Rodriguez A, Garcia Gala J, Martınez Revuelta E, et al. Use of extracorporeal photohersis: our experience in Sezary syndrome and erythrodermic mycosis fungoides. Vox Sanguinis. 2020; 115(Suppl. s1): 374.

9. Medina Guerrero E, Diaz Carbonero J, Perez Montana A. Results of extracorporeal photochemotherapy as treatment of chronic graft-versus-host disease in our center. Vox Sanguinis. 2020; 115(suppl. s1): 375.

10. Dann EJ, Eisa J, Badian A, et al. Comparison of extracorporeal photopheresis performed using Offline Spectra Optia ${ }^{\circledR}$ with continuous or intermittent mononuclear cell collection programs for the treatment of graft-versus-host disease. Vox Sanguinis. 2020; 115(suppl. s1): 369. 